\title{
Aplikasi Android Mengenal Tata Surya Berbasis Augmented Reality Sebagai Media Belajar Interaktif Siswa Sekolah Dasar
}

\author{
Galih Ashari Rakhmat \\ Program Studi Manajemen Informatika, Politeknik Praktisi Bandung, Indonesia \\ Email: asharilabs@gmail.com
}

\begin{abstract}
Abstrak
Penggunaan smartphone berbasis android saat ini sedang meningkat pesat. Hal ini membuat pengembang aplikasi berlomba untuk menciptakan berbagai aplikasi. Augmented Reality (AR) adalah suatu lingkungan yang memasukkan objek virtual 3D ke dalam lingkungan nyata. AR merupakan teknologi visualisasi yang saat ini sedang banyak dikembangkan di beberapa bidang. Aplikasi Augmented Reality di bidang pendidikan yang dikembangkan pada penelitian ini adalah membahas mengenai sistem Tata Surya untuk siswa sekolah dasar. Dengan penyajian konten aplikasi yang baik, daya imajinasi anak akan berkembang secara positif. Banyak media yang menjelaskan tentang sistem Tata Surya, seperti buku dan video. Namun, pengembangan media berbasis Augmented Reality ini diharapkan dapat memberikan insight tersendiri bagi para siswa. Penelitian ini telah berhasil mengembangkan suatu prototipe produk atau media berupa buku yang dapat diinteraksikan dengan aplikasi AR pada smartphone Android. Pembahasan pada penelitian ini akan dititikberatkan pada sisi aplikasi yang dirancang, bukan pada sisi perancangan buku interaktif. Adapun terkait tentang media buku interaktif, akan disajikan tampilan-tampilan visual buku yang sudah selesai dikembangkan. Pengujian aplikasi telah dilakukan dengan cara langsung berinteraksi dengan siswa tingkat pendidikan sekolah dasar, kemudian mereka memberikan tanggapan pada kuisioner. Hasil dari pengujian tersebut adalah, tingkat usability dari aplikasi mendapatkan respon yang baik dan mudah untuk digunakan oleh siswa sekolah dasar.
\end{abstract}

Kata Kunci: Augmented Reality; Media Interaktif; Smartphone; Android; Tata Surya

\begin{abstract}
The use of Android-based smartphones is currently increasing rapidly. This makes application developers compete to create various applications. Augmented Reality (AR) is an environment that inserts 3D virtual objects into a real environment. AR is a visualization technology that is currently being developed in several fields. Augmented Reality application in the field of education developed in this study is to discuss the solar system for elementary school students. By presenting a good application content, children's imagination will develop positively. Many media explain about the solar system, such as books and videos. However, the development of Augmented Reality-based media is expected to provide its own insights for students. This research has successfully developed a prototype of a product or media in the form of a book that can be interacted with the AR application on an Android smartphone. The discussion in this study will focus on the application side designed, not on the interactive book design side. Regarding the interactive book media, visual displays of books which have been developed. Application testing has been done by directly interacting with students at the elementary school level, then they respond to the questionnaire. The results of these tests are, the level of usability of the application gets a good response and is easy for use by elementary school students.
\end{abstract}

Keywords: Augmented Reality; Interactive Media; Smartphone; Android; Solar System

\section{PENDAHULUAN}

Seiring dengan perkembangan teknologi di era modern ini, komputer memiliki banyak manfaat bagi manusia dalam berbagai bidang, beberapa diantaranya seperti pendidikan, pariwisata, hiburan, dan komunikasi. Kemudahan dalam mengolah akses layanan informasi menjadi salah satu pilihan bagi setiap pengguna perangkat komunikasi. Salah satunya yang sekarang ini sedang banyak digunakan adalah smartphone. Perangkat ini banyak memberikan kemudahan bagi manusia untuk mengakses berbagai macam informasi melalui jaringan internet. Pengguna smartphone berbasis android saat ini sedang meningkat pesat. Hal ini membuat pengembang aplikasi banyak yang berlomba untuk menciptakan berbagai aplikasi di android. Salah satu media pendukung dalam proses pembelajaran yang menarik saat ini salah satunya adalah Augmented Reality. Teknologi Augmented Reality ini merupakan suatu sistem pembacaan marker yang sebelumnya sudah dibuat [1]. Selain itu, Augmented Reality dapat dikatakan sebagai teknologi yang menggabungkan objek virtual ke dalam dunia nyata, sehingga user dapat melihat dan berinteraksi dengan objek virtual tersebut di dunia nyata [2] [3]. Unsur reality lebih diutamakan dalam sistem ini. Augmented Reality dapat diaplikasikan ke dalam smartphone sebagai aplikasi berbasis android menggunakan Unity 3D. Salah satu keuntungan dengan adanya teknologi Augmented Reality yang berkaitan dengan siswa tingkat sekolah dasar, adalah Augmented Reality ini bersifat sangat menyenangkan, baik dari sisi implementasi ataupun penggunaannya [4]. Dengan demikian, seorang penyelenggara pendidikan ataupun guru harus mengetahui bahwa learning process adalah suatu hal yang menuntut akan kretivitas dan interaksi [5].

Aplikasi AR di bidang pendidikan yang dikembangkan pada penelitian ini, memiliki konten tentang pengenalan sistem Tata Surya. Dengan tema konten aplikasi berupa sistem Tata Surya, siswa dapat mengetahui bermacam-macam benda langit di luar angkasa dan juga planet serta bintang-bintang. Dunia luar angkasa bagi anak, dapat menimbulkan fantasi. Dengan penjelasan yang baik, fantasi yang tumbuh dan berkembang pada anak umumnya akan dapat tumbuh secara positif. Selain itu, karena mempelajari dunia luar angkasa sangat berkaitan dengan ilmu alam, daya tarik mereka pun bisa menumbuhkan keinginan belajar terhadap ilmu alam menjadi besar. 
Sudah banyak media yang menjelaskan tentang sistem Tata Surya, seperti halnya buku dan video. Teknologi Augmented Reality dapat digunakan untuk memperkenalkan materi sistem Tata Surya secara menarik.

Berdasarkan paparan tersebut maka masalah yang telah dirumuskan pada penelitian ini, adalah mengenai bagaimana merancang serta mengembangkan suatu media pembelajaran interaktif menggunakan smartphone berbasis augmented reality untuk materi ajar tentang Tata Surya. Selain itu juga dilakukan analisa secara statistika deskriptif mengenai bagaimana respon dari siswa tingkat sekolah dasar mengenai aplikasi yang telah dikembangkan tersebut. Inovasi untuk mengembangkan suatu aplikasi augmented reality ini diharapkan dapat menjadi media penunjang bagi para siswa untuk belajar mengenai sistem Tata Surya.

\section{METODE PENELITIAN}

Fokus utama yang menjadi output dari penelitian ini adalah untuk mengembangkan suatu produk aplikasi android berbasis augmented reality bernama menjelajah Tata Surya, yang dapat menunjang serta menjadi pelengkap untuk kegiatan pembelajaran siswa tingkat sekolah dasar untuk materi mengenai sistem Tata Surya. Produk tidak hanya dapat diartikan sebagai barang yang ada fisiknya ataupun berwujud saja. Sukmadinata dalam Putri Nandita dan Swaditya, menyatakan bahwa produk tidak selalu berbentuk benda atau perangkat keras seperti buku, modul, media pembelajaran di kelas atau di laboratorium, tetapi dapat juga berupa perangkat lunak atau program komputer, model pendidikan, pembelajaran ataupun pelatihan [6].

\subsection{Desain Penelitian}

Pada penelitian ini digunakan metode penelitian research and development (R\&D). Dasar yang diambil untuk melakukan penelitian dengan metode R\&D ini adalah dari Borg \& Gall, yang menyatakan bahwa Educational Research and Development is a process used to develop and validate educational products [7]. Dari sumber yang lain menyatakan bahwa metode penelitian R\&D digunakan untuk menghasilkan produk tertentu dan menguji keefektifan produk tersebut [8].

\subsection{Prosedur Penelitian}

Dari sisi user atau pengguna, pembangunan aplikasi mengenal Tata Surya berbasis augmented reality ini ditujukan untuk para siswa, yaitu menjadi media penunjang kegiatan belajar. Secara tidak langsung, produk ini sangat erat kaitannya dengan bidang pendidikan. Maka dari itu metode penelitian yang dipilih adalah sangat beralasan untuk menggunakan Research and Development (R\&D), karena ide dasar yang digunakan adalah dari Borg \& Gall (1979) serta Sugiyono (2009). Dengan demikian dua bidang utama di penelitian ini, yaitu pendidikan dan informatika, akan mengkombinasikan dua prosedur, yaitu prosedur untuk Educational Research and Development, serta prosedur mengembangkan perangkat lunak. Berikut ini merupakan tahapan-tahapan dari prosedur Educational Research and Development yang diungkapkan oleh Borg dan Gall [7].

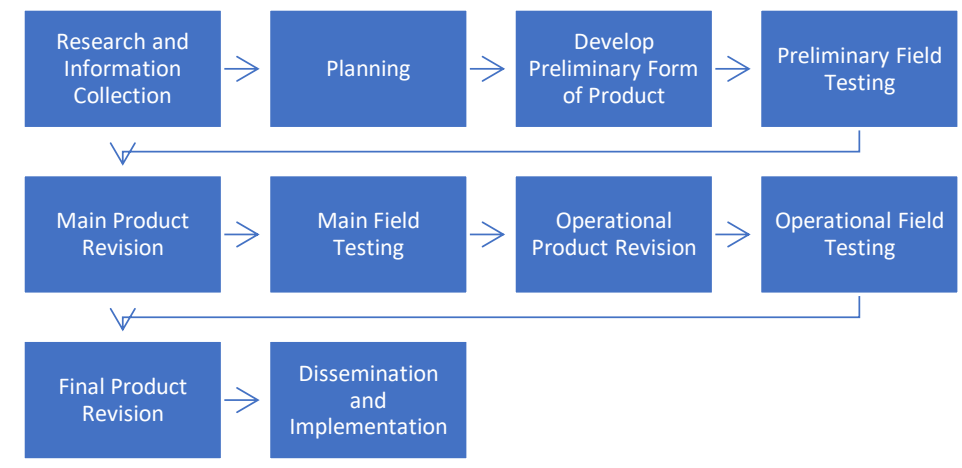

Gambar 1. Tahapan Educational Research and Development Borg dan Gall (1989)

Tahapan rekayasa perangkat lunak merupakan proses yang sangat dominan pada penelitian ini, yaitu untuk mengembangkan suatu aplikasi menjelajah Tata Surya berbasis augmented reality. Menurut Sukamto, Ariani Rosa, dan M. Shalahuddin dalam Nur Hidayat [9][10], mengatakan bahwa, tahapan umum dalam pengembangan perangkat lunak dengan model waterfall adalah sebagai berikut.

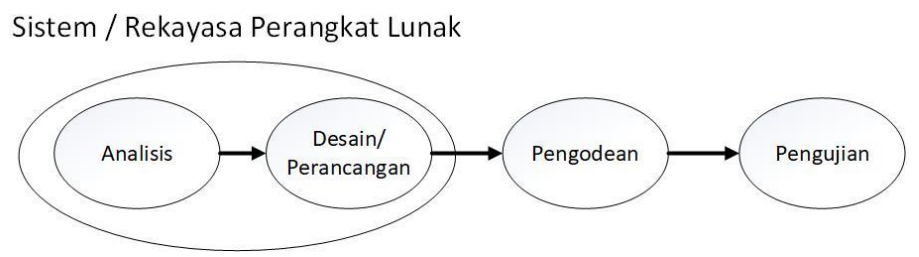

Gambar 2. Tahapan Rekayasa Perangkat Lunak Sukamto \& M. Shalahuddin (2013) 
Pada gambar 2 tahapan rekayasa perangkat lunak dapat dilihat bahwa pada tahapan awal perekayasaan perangkat lunak terdiri dari dua bagian, yaitu analisis dan desain/perancangan. Terdapat proses yang berurutan dimulai dari analisis kemudian desain/perancangan, kemudian masuk kepada proses pengodean dan yang terakhir adalah proses pengujian. Prosedur penelitian yang digunakan pada penelitian ini adalah mengkombinasikan diantara tahapan Educational Research and Development, serta tahapan Rekayasa Perangkat Lunak. Dengan demikian tahapantahapan dari prosedur penelitian ini adalah sebagai berikut.

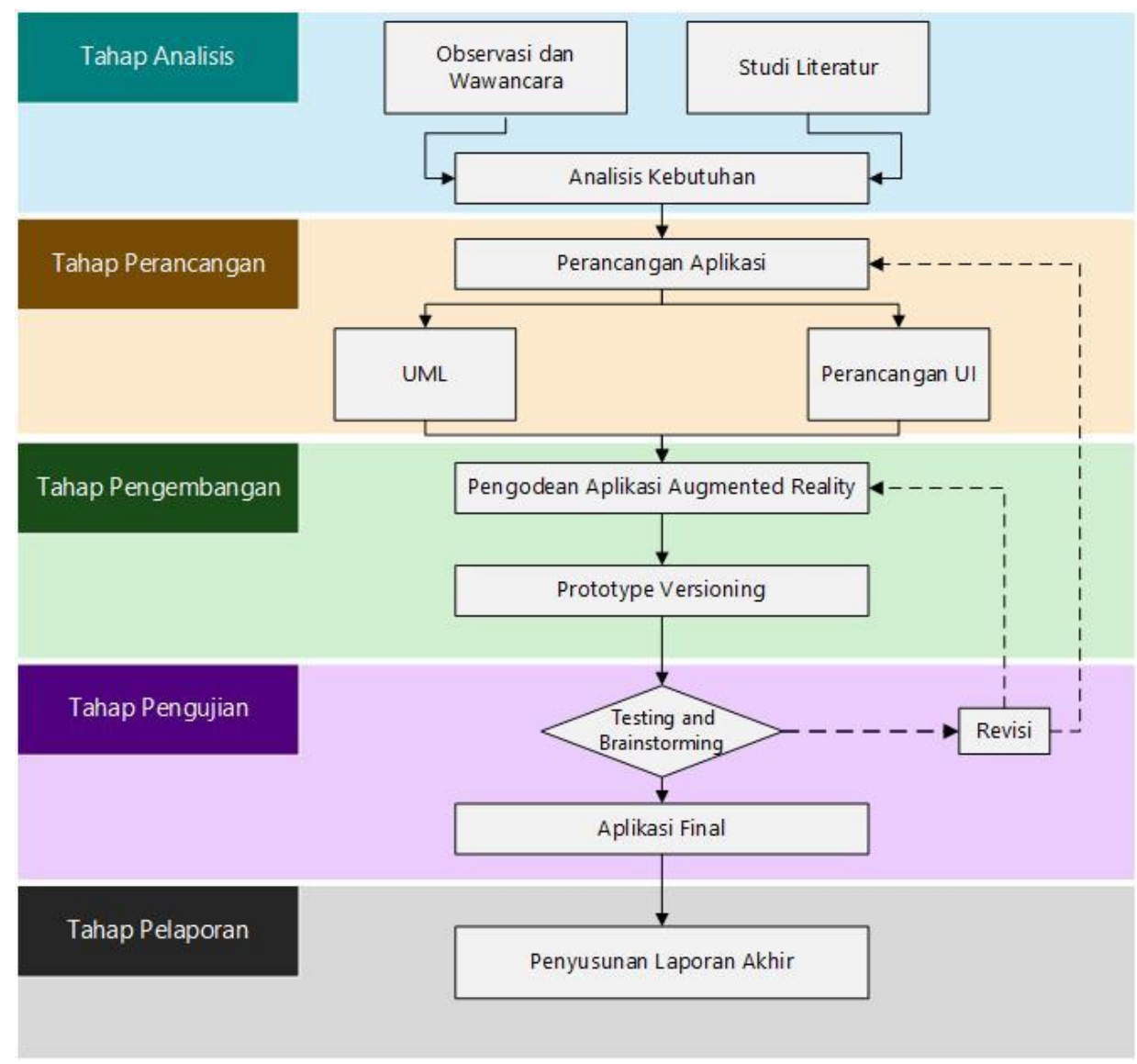

Gambar 3. Prosedur Penelitian

Adapun prosedur penelitian yang telah dirumuskan pada Gambar 3, telah dilakukan selama waktu pengerjaan penelitian ini. Berikut adalah perincian kegiatan yang dilakukan.

a. Tahap Analisis, pada tahapan ini peneliti melakukan kunjungan terlebih dahulu ke SDN 139 Sukarasa. Dasar pemilihan lokasi atau tempat dilakukannya penelitian ini, adalah karena pertimbangan geografis, yaitu jarak tempuh yang sangat memungkinkan untuk merancang suatu media ajar interaktif. Proses yang dilakukan adalah dengan melakukan observasi lapangan dan wawancara. Kegiatan observasi lapangan ini bertujuan mengamati tingkah laku siswa sekolah dasar yang menjadi user aplikasi yang dikembangkan ini. Selain itu juga, wawancara baik itu ke siswa ataupun ke guru mata pelajaran telah dilakukan secara menyeluruh untuk mendapatkan data-data awal. Selain itu, kegiatan studi literatur dilakukan untuk melakukan kajian pustaka serta mencari referensi aplikasi yang akan dikembangkan.

b. Tahap Perancangan, pada tahapan ini terdapat dua sub proses yang dilakukan sebagai follow-up hasil dari tahapan analisis, yaitu UML dan perancangan UI. Hal yang paling diperhatikan baik dari sisi user experience (UML) dan dari sisi user interface adalah user yang akan menggunakan aplikasi ini adalah siswa sekolah dasar kelas 4. Dengan demikian dari desain aplikasi serta interaksi akan disesuaikan dengan kategori anak-anak, yaitu menarik dan mudah digunakan.

c. Tahap Pengembangan, setelah tahap perancangan dapat dikatakan cukup, selanjutnya adalah melakukan pengodean aplikasi. Engine yang digunakan adalah Unity 3D, sedangkan engine untuk Augmented Reality menggunakan Vuforia. Hasilnya adalah sebuah aplikasi purwarupa dengan nomor versi yang saling increamental. Setelah semua tahapan selesai, maka tahap terakhir untuk memperoleh installer aplikasi android berbasis augmented reality ini, adalah melakukan kompilasi file APK dari Unity 3D.

d. Tahap Pengujian, aplikasi yang masih berupa purwarupa dan telah selesai dikembangkan secara pengodean, selanjutnya akan dilakukan testing, baik secara developer review ataupun limited user review, yaitu kepada beberapa orang siswa dan guru. Pengujian dari sisi developer, akan dilihat terkait bugs ataupun fungsionalitas yang lainnya. Dari sisi user siswa, akan dilihat lebih kepada user experience, bagaimana siswa memegang 
smartphone dan berinteraksi dengan aplikasinya. Dan dari sisi guru, akan ditinjau lebih kepada materi yang disampaikan pada aplikasi menjelajah Tata Surya berbasis augmented reality ini. Pada pelaksanaannya, terdapat beberapa revisi yang dihimpun setiap pengujian.

Tabel 1. Revisi Purwarupa Aplikasi Tiap Versi

\begin{tabular}{|c|c|c|c|}
\hline Revisi ke- & Developer Review & Guru Review & Siswa Review \\
\hline 1.0 & - & $\begin{array}{l}\text { Penambahan informasi } \\
\text { tambahan setiap planet, } \\
\text { seperti lama waktu } \\
\text { revolusi dan rotasi }\end{array}$ & $\begin{array}{l}\text { Posisi tombol-tombol } \\
\text { harus disesuaikan dengan } \\
\text { panjang jari standar anak } \\
\text { SD }\end{array}$ \\
\hline 1.1 & $\begin{array}{l}\text { - Share capture tidak } \\
\text { bisa diakses setelah } \\
\text { revisi dari siswa } \\
\text { review }\end{array}$ & - & $\begin{array}{l}\text { Perputaran planet (rotasi) } \\
\text { terlalu cepat, perlu } \\
\text { dikurangi }\end{array}$ \\
\hline 1.2 & $\begin{array}{l}\text { Optimasi memory } \\
\text { leak pada } \\
\text { smartphone dari } \\
\text { objek-objek yang } \\
\text { tidak dimunculkan }\end{array}$ & 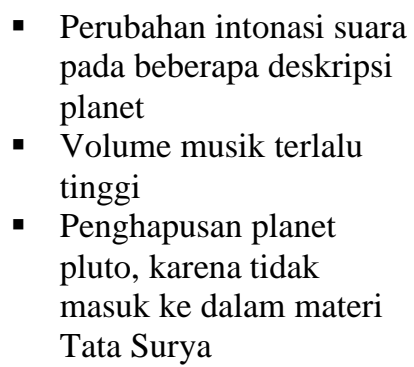 & $\begin{array}{l}\text { - Audio deskripsi planet } \\
\text { tidak jelas, karena volume } \\
\text { untuk background music } \\
\text { terlalu tinggi } \\
\text { - Kamera terkadang tidak } \\
\text { fokus ketika didekatkan } \\
\text { pada marker }\end{array}$ \\
\hline 1.3 & $\begin{array}{l}\text { - Revisi audio } \\
\text { penjelasan deskripsi } \\
\text { planet }\end{array}$ & - & - \\
\hline
\end{tabular}

e. Tahap Pelaporan, pada tahapan ini semua dokumentasi telah disusun sebagai bukti penelitian telah dilakukan.

\section{ANALISA DAN PEMBAHASAN}

Pemaparan mengenai analisa dan pembahasan ini difokuskan dari sisi pengembangan aplikasi menjelajah Tata Surya, sedangkan untuk perancangan buku interaktif tidak akan dibahas secara detail, hanya dimunculkan saja tampilan buku yang sudah jadi.

\subsection{Unified Modeling Language (UML)}

UML yang dibahas adalah use case diagram. Pada bagian use case ini, aktor user adalah siswa tingkat sekolah dasar yang dapat melakukan use case menyorot marker, kemudian siswa dapat melakukan screen capture (menangkap gambar/layar/image), dan yang terakhir adalah dapat membagikannya ke aplikasi-aplikasi social media yang terinstal pada smartphone.

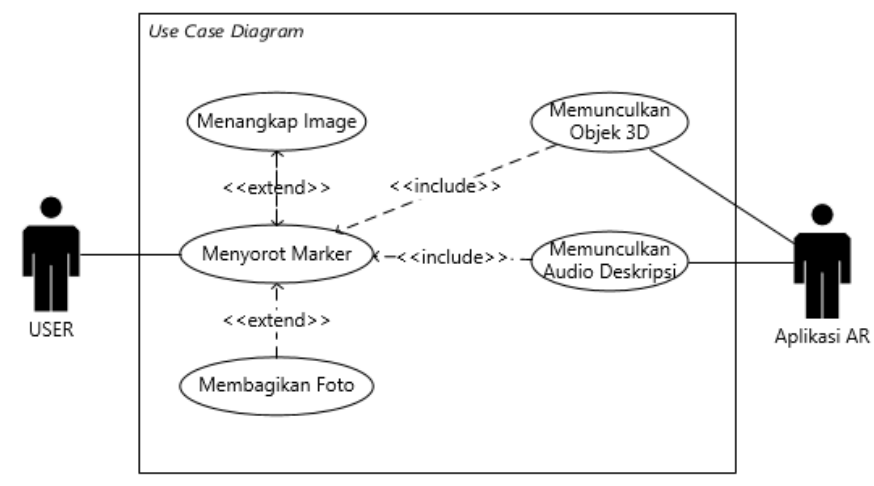

Gambar 4. Use Case aplikasi AR Tata Surya

Aktivitas dari aktor user yang akan menjadi main core activity dari aplikasi augmented reality ini adalah pada use case menyorot marker. Pada use case ini, siswa mengarahkan smartphone pada marker, yang kemudian aplikasi akan memunculkan objek 3D berupa planet beserta texture yang sedang melakukan rotasi, serta audio penjelasan dari planet tersebut. Use case selanjutnya dapat dilakukan oleh user untuk melakukan screen capture dari tombol yang disediakan. Secara fungsionalitas, ketika tombol screen capture diklik, maka image sudah 
otomatis disimpan di folder lokal smartphone. Jika user tidak akan melakukan share terhadap image hasil capture tersebut, maka akan kembali ke halaman utama AR untuk menyorot marker. Social media yang dapat dijadikan media untuk share hasil capture tersebut tergantung dari aplikasi-aplikasi social media yang terinstal pada smartphone.

\subsection{Interface Aplikasi Augmented Reality Menjelajah Tata Surya}

Berikut ini adalah keseluruhan halaman yang telah dikembangkan pada aplikasi mengenal Tata Surya berbasis augmented reality. Proses perancangan user interface telah berhasil dilalui, selanjutnya adalah halaman implementasi hasil pembangunan.

\section{a. Halaman Cover}

Pada halaman cover ini, user dihadapkan dengan beberapa interaksi tombol, seperti tombol play, tombol keluar (exit), serta tombol bantuan yaitu tatacara penggunaan aplikasi dan seputar aplikasi.

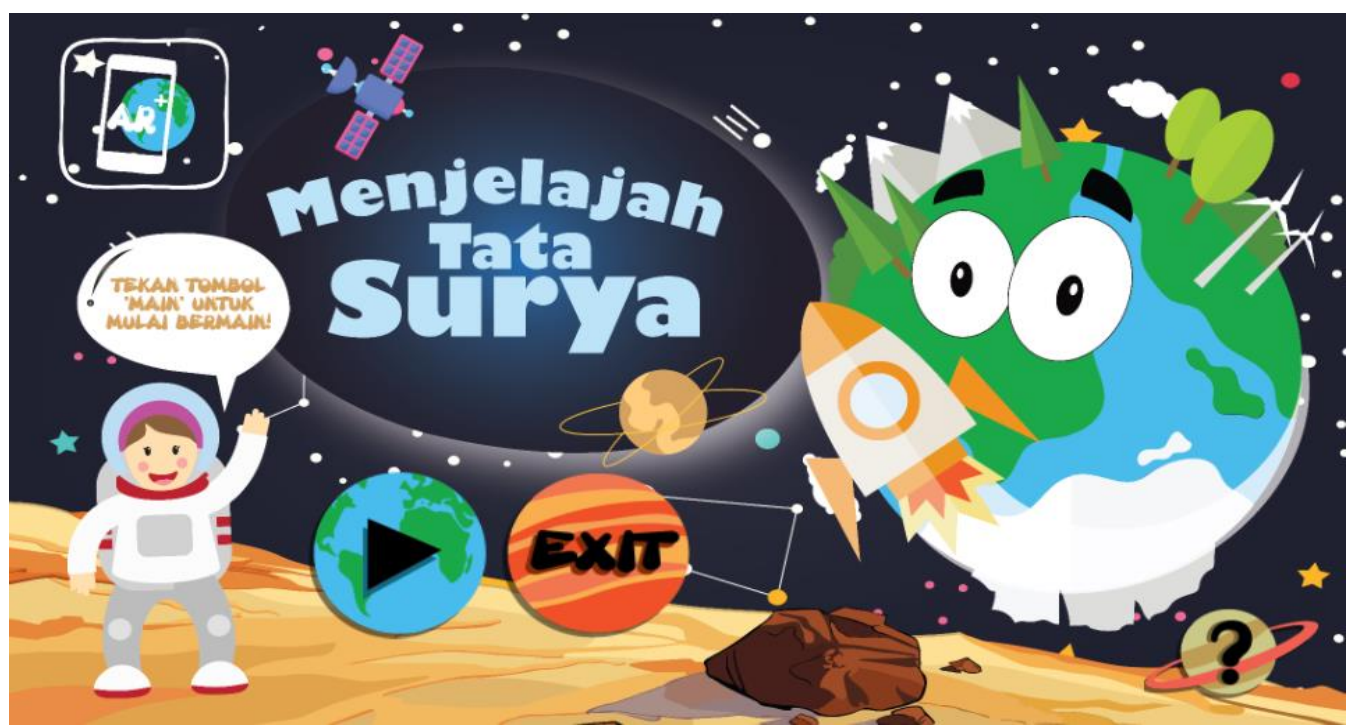

Gambar 5. User Interface Halaman Cover

\section{b. Halaman Utama AR}

Pada halaman utama AR ini adalah tampilan yang akan sering user melakukan aktivitas sistem, seperti menyorot marker, kemudian muncul objek 3D dan audio penjelasan mengenai deskripsi dari planet tersebut. User dapat mencari beberapa sudut sorot tertentu yang dinilai layak dan menarik untuk melihat objek 3D. Pada tampilan ini juga, objek 3D telah disesuaikan dengan aktivitas planet itu sendiri, yaitu rotasi. Objek 3D melakukan rotasi yang menunjukkan secara materi bahwa planet melakukan rotasi. Dari halaman ini juga, user dapat melakukan use case yang lain, yaitu melakukan capture screen yang kemudian dapat membagikannya (share) ke social media. Tampilan dari halaman utama aplikasi AR mengenal Tata Surya dapat dilihat pada gambar berikut ini.

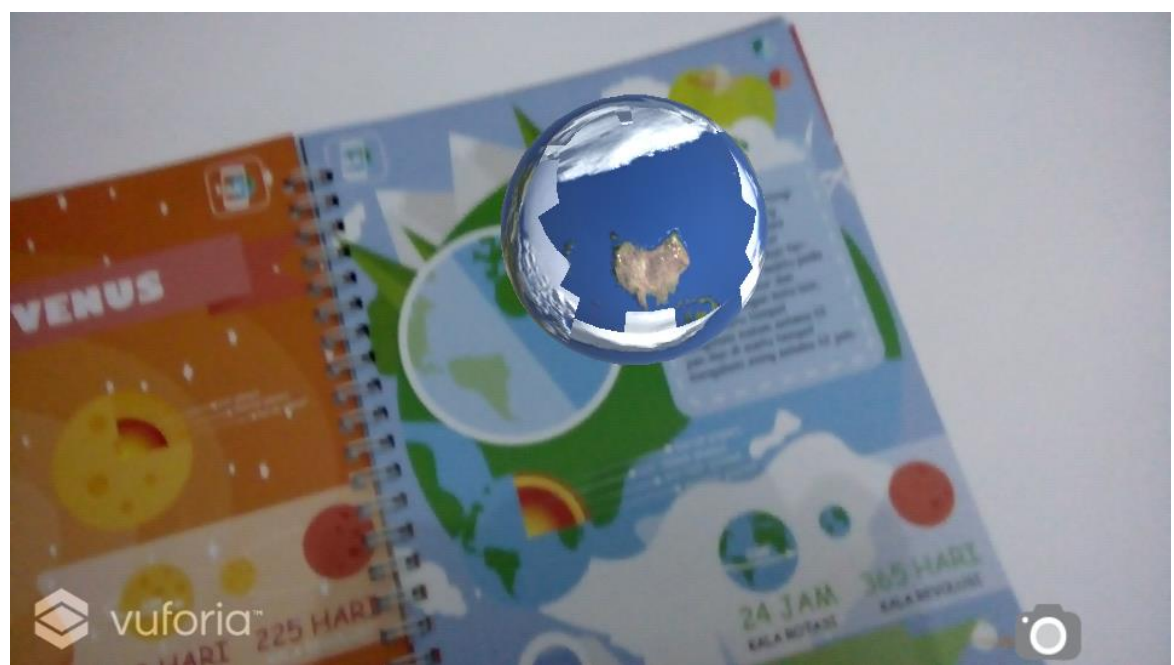

Gambar 6. User Interface Halaman Utama AR 
Building of Informatics, Technology and Science (BITS)

Volume 2, No 2, December 2020 Page 151-158

ISSN 2684-8910 (media cetak)

ISSN 2685-3310 (media online)

\section{c. Halaman Capture Screen}

Pada halaman capture screen ini, prinsipnya adalah saat menekan tombol capture screen pada halaman utama, maka gambar akan tersimpan otomatis ke dalam folder lokal di smartphone user. Tombol merupakan elemen dinamis pada suatu Graphical User Interface, yaitu elemen kontrol [11]. Selanjutnya, pada halaman capture screen ini akan muncul icon-icon aplikasi social media yang telah terinstal di smartphone. Berikut ini adalah tampilan halaman capture screen.

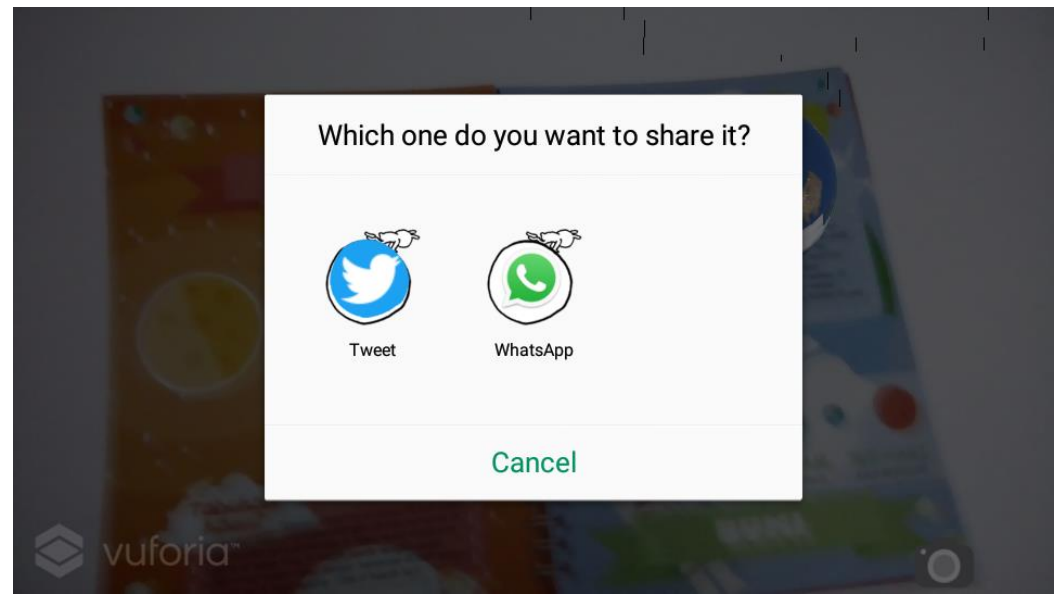

Gambar 7. User Interface Halaman Capture Screen

\section{d. Halaman Share}

Pada halaman share ini, terdapat tulisan yang sudah diatur standar dari aplikasi, yaitu Menjelajah Tata Surya untuk Anak Usia Sekolah Dasar. Tampilan user interface untuk masing-masing social media akan berbeda, namun pada dasarnya akan terdapat beberapa komponen yang sama, yaitu Text, Image, Tombol Share tergantung social media, yang berbeda adalah Tag Location, Tag Friend. Gambar berikut ini apabila aplikasi social media adalah twitter, maka tampilannya adalah sebagai berikut.

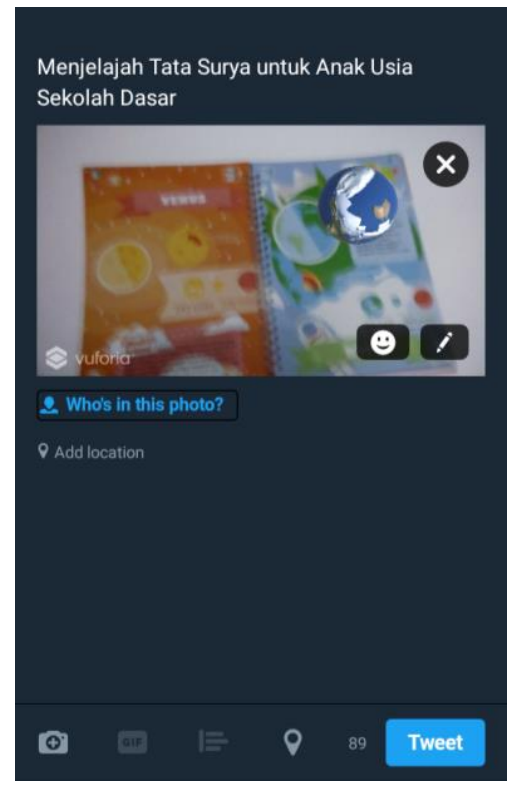

Gambar 8. User Interface Halaman Share

\subsection{Pengujian Aplikasi}

Sebagaimana yang telah dibahas sebelumnya dari Borg and Gall (1989), bahwa aplikasi yang dikembangkan harus dilakukan beberapa pengujian sehingga didapatkan aplikasi yang memang sudah fixed pada versi tersebut. Pengujian dilakukan di lokasi diselenggarakannya penelitian ini, yaitu di Sekolah Dasar Negeri 139 Sukarasa, yang beralamat di jalan Gegerkalong Hilir No. 82 Bandung 40153. Subjek dari penelitian ini adalah siswa sekolah dasar. Populasi yang diambil hanya dua kelas saja dengan total yaitu sebanyak 60 siswa, yaitu kelas 4A sebanyak 30 siswa dan kelas 4B sebanyak 30 siswa. 
Tidak ada treatment atau perlakuan yang dibedakan diantara kedua kelas tersebut, karena pada penelitian ini yang diteliti atau diuji adalah hasil rancangan atau pengembangan dari aplikasi menjelajah Tata Surya berbasis augmented reality. Pengujian yang dilakukan adalah setiap siswa mencoba belajar mengenai Tata Surya dengan menggunakan aplikasi tersebut, setelah semuanya mencoba maka selanjutnya adalah mengisi kuisioner yang diberikan serta melakukan wawancara. Analisa data menggunakan statistika deskriptif, Hasan dalam Leni (2017) menyatakan bahwa statistika deskriptif hanya berhubungan dengan hal menguraikan atau memberikan keteranganketerangan atau fenomena atau keadaan mengenai satu kelompok data [12]. Fenomena yang akan dilakukan perhitungan pada penelitian ini adalah nilai persentase dari respon siswa terhadap materi yang diuji, yaitu konten, multimedia, usability, dan user experience.

Pertanyaan nomor satu dan dua menyangkut masalah konten materi serta multimedia, sedangkan untuk pertanyaan nomor tiga dan empat menyangkut tentang kemudahan penggunaan ataupun user experience dari aplikasi yang dikembangkan ini. Hasil dari rekapitulasi angket responden yang diambil dari kedua kelas, dapat dilihat pada gambar sebagai berikut.

Tabel 2. Rekapitulasi Responden Terhadap Konten Materi AR

\begin{tabular}{lcc}
\hline 1. Dengan menggunakan aplikasi AR Tata Surya ini, saya merasa & $\mathrm{N}$ & $\%$ \\
\hline terbantu untuk memahami materi yang disampaikan & & $99.33 \%$ \\
Sangat Setuju & 1 & $1.67 \%$ \\
Setuju & 0 & $0 \%$ \\
Tidak Setuju & 0 & $0 \%$ \\
Sangat Tidak Setuju & $\mathbf{6 0}$ & $\mathbf{1 0 0 \%}$ \\
\hline
\end{tabular}

Tabel 3. Rekapitulasi Responden Terhadap Multimedia

\begin{tabular}{lcc}
\hline 2. Tampilan gambar-gambar yang ada di buku ataupun di aplikasi & $\mathrm{N}$ & $\%$ \\
\hline \multicolumn{1}{c}{ ini sangat menarik } & 56 & $93.33 \%$ \\
Sangat Setuju & 4 & $6.67 \%$ \\
Setuju & 0 & $0 \%$ \\
Tidak Setuju & 0 & $0 \%$ \\
Sangat Tidak Setuju & $\mathbf{6 0}$ & $\mathbf{1 0 0 \%}$ \\
\hline Total
\end{tabular}

Tabel 4. Rekapitulasi Responden Terhadap Usability

\begin{tabular}{lcc}
\hline 3. Aplikasi ini sangat mudah untuk digunakan oleh saya ketika & $\mathrm{N}$ & $\%$ \\
\multicolumn{1}{c}{ mempelajari materi tentang Tata Surya } & 55 & $91.67 \%$ \\
\hline Sangat Setuju & 0 & $0 \%$ \\
Setuju & 4 & $6.67 \%$ \\
Tidak Setuju & 1 & $1.67 \%$ \\
Sangat Tidak Setuju & $\mathbf{6 0}$ & $\mathbf{1 0 0 \%}$ \\
\hline Total
\end{tabular}

Tabel 5. Rekapitulasi Responden Terhadap User Experienced

\begin{tabular}{lcc}
\hline 4. Musik dan suara penjelasan materi tentang planet sangat jelas & $\mathrm{N}$ & $\%$ \\
$\quad$ dan mudah didengar & 50 & $83.33 \%$ \\
Sangat Setuju & 8 & $13.33 \%$ \\
Setuju & 2 & $3.33 \%$ \\
Tidak Setuju & 0 & $0 \%$ \\
Sangat Tidak Setuju & $\mathbf{6 0}$ & $\mathbf{1 0 0 \%}$ \\
\hline Total & &
\end{tabular}

Hasil yang didapat adalah sebagai berikut.

Tabel 6. Rekapitulasi Hasil Angket Respon Sangat Baik

\begin{tabular}{llc}
\hline No. & \multicolumn{1}{c}{ Materi Uji } & Respon Sangat Baik (\%) \\
\hline 1. & Pemahaman materi Tata Surya menggunakan aplikasi & $98.33 \%$ \\
2. & Tampilan visual buku dan aplikasi & $93.33 \%$ \\
3. & Kemudahan penggunaan aplikasi & $91.67 \%$ \\
4. & Penjelasan secara audio & $83.33 \%$ \\
\hline
\end{tabular}


Berdasarkan tabel 6, dapat disimpulkan secara deskriptif bahwa di atas 80\% semua siswa kelas 4 tingkat sekolah dasar menyatakan sangat baik terhadap semua materi yang telah dirancang di dalam aplikasi yang telah dikembangkan pada penelitian ini, yaitu konten materi Tata Surya, Multimedia, Usability, dan User Experience.

\section{KESIMPULAN}

Tujuan awal yang dicapai pada penelitian ini adalah, dapat melakukan perancangan dan pengembangan aplikasi yang dijalankan pada platform android berbasis augmented reality tentang sistem Tata Surya di tingkat siswa sekolah dasar. Perancangan aplikasi dan buku telah selesai dilaksanakan, begitu juga dengan telah dilakukannya pengujian akhir terhadap siswa kelas 4 tingkat sekolah dasar. Proses pengumpulan data dilakukan dengan cara menyebarkan angket berskala likert, untuk mengetahui respon dari beberapa materi yang diujikan.

Adapun revisi aplikasi pada tahapan terakhir telah dilakukan, yaitu perbaikan audio penjelasan deskripsi setiap planet.

\section{UCAPAN TERIMAKASIH}

Penelitian ini telah banyak melibatkan pihak yang dapat mewujudkan tujuan akhir dari penelitian ini, yaitu pembangunan aplikasi dari sisi visual dan audio. Selain itu, ijin yang diberikan dari pihak Sekolah Dasar Negeri 139 Sukarasa. Terimakasih disampaikan kepada Annisa Shafira Riama, sebagai 2D artist dan audio engineer yang telah melengkapi aplikasi sehingga selesai pada tahap pertama ini. Kemudian yang terakhir adalah kepada pihak Sekolah Dasar Negeri 139 Sukarasa, baik kepada para ibu guru pengajar kelas 4A dan 4B, kepala sekolah beserta para staff, serta tidak lupa kepada para siswa kelas 4A dan 4B.

\section{REFERENCES}

[1] R. D. A. Budiman, “Developing Learning Media Based on Augmented Reality (Ar) To Improve Learning Motivation,” JETL (Journal Educ. Teach. Learn., vol. 1, no. 2, p. 89, 2016, doi: 10.26737/jetl.v1i2.45.

[2] B. Afandi, I. Kustiawan, and N. D. Herman, "Exploration of the augmented reality model in learning," J. Phys. Conf. Ser., vol. 1375, no. 1, 2019, doi: 10.1088/1742-6596/1375/1/012082.

[3] Y. Chen, Q. Wang, H. Chen, X. Song, H. Tang, and M. Tian, “An overview of augmented reality technology,” J. Phys. Conf. Ser., vol. 1237, no. 2, 2019, doi: 10.1088/1742-6596/1237/2/022082.

[4] J. F. Santos and S. M. Esposo-Betan, “Advantages and Challenges of Using Augmented Reality for Library Orientations in an Academic/ Research Library Setting," Proc. IATUL Conf., vol. Paper 7, 2017, [Online]. Available: https://docs.lib.purdue.edu/iatul/2017/challenges/7.

[5] M. F. Hossain, S. Barman, and A. K. M. B. Haque, “Augmented Reality for Education; AR Children's Book," TENCON 2019 - 2019 IEEE Reg. 10 Conf., pp. 2568-2571, 2019, doi: https://doi.org/10.1109/TENCON.2019.8929565.

[6] P. N. Apsari and S. Rizki, "MEDIA PEMBELAJARAN MATEMATIKA BERBASIS ANDROID PADA MATERI PROGRAM LINEAR," J. Pendidik. Mat. FKIP Univ Muhammadiyah Metro Aksioma, vol. 7, no. 1, pp. 161-170, 2018.

[7] W. R. Borg and M. D. Gall, Educational Research: An Introduction, 5th ed. New York \& London: Longman, 1989.

[8] Hanafi, "Konsep Penelitian R \& D Dalam Bidang Pendidikan," Saintifika Islam. J. Kaji. Keislam., vol. 4, no. 2, pp. 129-150, 2017.

[9] H. Nur, "Penggunaan Metode Waterfall Dalam Rancang Bangun Sistem Informasi Penjualan," Gener. J., vol. 3, no. 1, p. 1, 2019, doi: 10.29407/gj.v3i1.12642.

[10] Sukamto, A. Rosa, and M. Shalahuddin, Rekayasa Perangkat Lunak Terstruktur dan Berorientasi Objek. Bandung: Informatika, 2018.

[11] D. Saha and A. Mandal, "User Interface Design Issues for Easy and Efficient Human Computer Interaction: An Explanatory Approach," Int. J. Comput. Sci. Eng., vol. 3, no. 1, pp. 127-135, 2015.

[12] L. M. Nasution, "Statistika Deskriptif," J. Hikmah, vol. 14, no. 1, pp. 49-55, 2017. 